\title{
Islamic Concepts and Mining Practices in Cepu of Middle Java
}

\author{
$1^{\text {st }}$ Yoga Mulhadiono ${ }^{1}, 2^{\text {nd }}$ JM.Muslimin $^{2}, 3^{\text {rd }}$ Muammar Alwi $^{3}, 4^{\text {th }}$ Arif Zamhari $^{4}$ \\ \{ypmpringgo@gmail.com ${ }^{1}$, muslimin@uinjkt.ac.id ${ }^{2}$, muammar.alwi14@mhs.uinjkt.ac.id ${ }^{3}$, \\ arif.zamhari@uinjkt.ac.id $\left.{ }^{4}\right\}$
}

UIN Syarif Hidayatullah Jakarta ${ }^{1,2,3,4}$

\begin{abstract}
This study aims to see how the Islamic concept in terms of mining. Focus This research is on petroleum mining in Cepu village. The method used in the preparation of this research is descriptive method, which aims to explain an event that is taking place in the present and also in the past. As for the approach, this research uses a case study approach in the village of Cepu. The sources of data obtained are interviews with direct visits and observations on the production process and products produced by production wells. The results of this study indicate that the process of managing or producing oil that is carried out in a modern or traditional way is not following Islamic principles, because the traditional method still uses manual methods that can damage the environment, while modern management is only for personal economic interests.
\end{abstract}

Keywords: Cepu, Petroleum, Mining.

\section{Introduction}

A study conducted by Pertamina with Padjadjaran University and the Bandung Institute of Technology (ITB) in 1988, showed that the potential of Indonesia's Remaining Recoverable Reserve among Far Eastern countries is still dominant [1]. However, compared to Middle Eastern countries, Indonesia's potential is far below it [2]. One of them is mining located in the Cepu area, where Pertamina is the holder of the Mining Working Area (WKP) in the area, and a local Oil Company owned by the Regency Government; as a Contractor assisted by the Local Oil Miners Association. The Local Oil Miners Association is a sub-contractor other than the Local Cooperative as the manager of people's mining activities in Cepu. Pertamina can carry out "secondary production" with oil operators already operating in the country. The governance of oil mining cooperation between Pertamina and other operators, such as Pertamina EP Cepu, can increase production. If governance is better, there is no need to increase earnings that violate the rules. In contrast to the artisanal miners in Wonocolo, and several other areas, Cooking crude oil into fuel causes teak forest fires.

In other areas such as the Ledok field, the miners are more obedient to Pertamina's supervision, especially with the procedures for collecting production with their tank trucks and no cooking of crude oil. In this Ledok area, especially around the location of the Ledok-1 well, where Kiai Djatikusomo discovered oil for the first time, the forest looks intact, the fauna and flora are relatively well preserved. Around the oil wells, food crops such as cassava and sweet potatoes have been planted. The morphological integrity here is thought to have not changed much since the Pleistocene epoch, about one million years ago. 
Based on field comparative observation studies in Wonocolo, Kawengan, and Ledok as well as the history of petroleum production in these areas, it is said that the management of petroleum in the Wonocolo field has the potential for environmental damage to be getting worse, while the Kawengan field requires large investment so that small-scale miners cannot participate, and the Ledok field people can only participate as subcontractors who are paid based on transportation costs.

Mining activities that take place in a conducive and growing manner have resulted in prosperity starting from the inner circle of the main actors to their links and outer circle. Welfare is not only in the form of an increase in income but also in the impact of increasing the level of education and public health. Fair arrangements for all directly related parties, namely the Government, WKP holders, and business legality as well as miners as operators depending on the Indonesian government as a regulator. At this time the good intentions have been realized in the form of a Decree of the Minister of Energy and Mineral Resources issued last March2018. The contents of the letter provide people's mining permits in the summary of Pertamina's WKP and may only be carried out under Pertamina's technical supervision. The oil it produces can only be sold to Pertamina.

The role of the quality of Human Resources (HR) who also master petroleum technology and behave in an Islamic manner is very necessary. The role of this behavior is believed to be very potential considering our population of more than 260 million people of which more than $80 \%$ are Muslims. Islamic Understanding [3] in this petroleum production technology is believed to play a major role [4] in the Cepu Mining Work Area, it is important because it is now the largest onshore oil and gas producer nationally [5]. For this reason, there is a need for an in-depth study of Islamic principles in the management of oil and gas mining, without violating the provisions of the Law of the Republic of Indonesia.

\section{Methodology}

The method used in the preparation of this research is descriptive method, which aims to explain an event that is taking place in the present and also in the past. This descriptive method was chosen because it is adapted to the type of research that is technical, normative, and empirical. This normative data is then combined with empirical elements, namely looking at the procedures for managing oil and gas mining in sharia principles [6]. The approach used in this research is a case study approach, namely oil and gas mining in Cepu village. The data sources of this research are interviews with direct visits and observations on the production process and products produced by production wells.

\section{Result and Discussion}

\subsection{Traditional mining management in Cepu city}

Looking at the current people's oil mining in Ledok, we will find a stark contrast between the location of the people's mining and modern oil and gas mining in the Cepu Block. Refers to that the open-pit mining business system such as the Cepu Block mining always changes the landscape so that it changes the ecosystem and its natural habitat on a large scale. This will disrupt the balance of environmental functions and harm human life. 
Open-pit mining should be limited not only to cultivation areas but also to protected forest areas. Examples of exposed ecosystems and people's behavior that are increasingly damaged can be found in the Wonocolo area. Management of natural resources that still prioritizes the preservation of natural resources and the welfare of the people can be found in the Ledok area [7].

Ledok is a village that is very rich in potential natural resources apart from petroleum products, also agricultural products, forest products. Most of the residents of Ledok Village make a living as traditional oil miners. Traditional Mining Community Managed Miners start from the Ledok Oil Mining Field at a depth of 94m. In Ledok Village, there are currently 24 oil fields that are still managed by Pertamina and traditionally by PPML 4 wells [8].

The existence of traditional oil drilling activities carried out by the Ledok community has caused a process of change in the management pattern and system of the people involved in it. Mining groups whose mining applications have been approved will be included in insurance coverage. Villagers who have registered as traditional miners are entitled to an insurance policy even though they do not mine every day [9].

Old wells that have been successfully opened must be drained or cleaned before they are ready for operation. At the time of draining or cleaning the required workforce begins to decrease, because the role of human labor shifts to machines. The division of ownership began to be carried out depending on the group's agreement. The need for diesel and towing cars is considered separately from the operational phase.

The operational stage is carried out after the well is ready for production, meaning that after the draining is complete and ready to carry out the lifting of crude oil (crude oil). In this operation, those who work to operate the mine are called operators consisting of drivers and lead builders. The driver is in charge of pulling the bucket by car and the lead is in charge of spilling oil into the reservoir. The crude oil taken from the well is then handed over to Pertamina. Miners or those who manage old wells are rewarded in the form of tariffs for lifting and transporting crude oil.

The process of finding old wells from the bowels of the earth, as well as mining methods, is carried out in two ways, modern and traditional. The modern search for old wells is carried out by PT. Pertamina, and traditional by traditional miners who mostly come from the local area. If Pertamina uses the Sucker Rod Pump, which is also a simple technology driven by electric power supplied by PLN. In some locations, the Angguk Pump machine is adjacent to the dipper pump, which is constructed of three logs.

This mining area is the source point of old wells, mostly located in the area of teak trees belonging to forestry. Regulation of the Minister of Oil and Gas seems to conflict with the regulation of the Minister of Forestry. Armed with a persuasive and familial approach, the miners through the association or association of Miners can overcome this, therefore the technical field still needs to cooperate with the forestry apparatus.

Talking with local miners, there are obstacles in mining, including the lack of appropriate technology so that the mining process still uses human power. HR skills still need to be improved through training and education of PT. Pertamina. In addition to reducing the risk of accidents. Also need the help of PT. Pertamina in logging activities to determine the volume content of oil in the well. The information obtained avoids reckless actions to make new bore wells [10].

The impact of traditional oil mining can reduce the rate of teak theft. Because most of the perpetrators are absorbed in the traditional oil mining sector which can generate wages of at least Rp. 200 million every month managed by the association. The income, which is sometimes 
above operational costs, has the potential to help finance village development, which so far still relies on the district government budget.

According to the General Chairperson of APRI (Association of Indonesian People's Miners), Gatot Sugiharto, "It is proven that in people's mining areas, the people are prosperous. But in mining carried out by the company, the surrounding community is poor [11]," People's mining is carried out with very simple technology and almost without a mechanical system using only minimal operational standards.

\subsection{Modern mining management in Cepu city}

In 1987, based on the Decree of the Minister of Mines and Energy No. 0177/K/1987 dated March 5, 1987, the Mining Authority Area (WKP) covering an area of $973 \mathrm{~km} 2$ which was originally managed by PPT Migas was handed over to Pertamina UEP III in the Cepu field. The area is located in 4 districts, namely Grobogan, Blora, Bojonegoro, and Tuban. The last two districts are in East Java. Through the handover of this WKP, several oil fields, namely Kawengan, Ledok Field, Wonocolo Village, Bojonegoro, and Nglobo/Semanggi districts, which consist of 519 oil wells, have been transferred to Pertamina UEP III.

The government's policy is based on Law no. 44 of 1960 in conjunction with Law no. 8 of 1971.[12] The law stipulates that the power to mine oil and gas in Indonesia is given to Pertamina as the only BUMN that manages oil and gas. Pertamina UEP III Cepu itself drilled the first oil field in 1989 in Blora Regency, Central Java.[13] The Cepu oil production field is divided into 2 districts, 1 Kawengan which has been developed since 1926, of which currently 76 active wells are covering the Kawengan and Wonocolo fields located in Bojonegoro and Tuban regencies. District 2, which includes the Ledok and Ngelobo fields, has been developed since 1896 with 51 active wells, including the Banyu Asin, Semanggi, Ledok and Banyu Abang fields.

Ledok Field is located $11 \mathrm{~km}$ northwest of the city of Cepu is an anticline with a length of $2.5 \mathrm{~km}$ and a width of $1.25 \mathrm{~km}$ with a height of $180 \mathrm{~km}$ above sea level. This field has been developed since 1896 and consists of 3 production areas, Ngelebur (12 wells), Ledok (235 wells with maximum depth 1,343 m), and Gelur 4 wells. Until 1995 there were still new wells drilled by Pertamina, one of which was well 252 .

The Ngelobo field, developed in 1903, is located $28 \mathrm{~km}$ west of Cepu with a height of 90 $\mathrm{m}$ above sea level, which is an anticline with a length of $1.5 \mathrm{~km}$ and a width of $0.5 \mathrm{~km}$. 47 wells were drilled with 9 layers with an average depth of $400-1,200 \mathrm{~m}$, three of which were drilled by Pertamina. The wells produced 38 pieces and the rest did not produce anything. Drilling towards Jepon and Semanggi in 1986, from drilling 86 productive wells, 66 wells, and those that did not produce 20 wells. Between 100-1270 m depth, 6 layers produce oil [14]. The peak was in 1986 which reached 2300 barrels/day, since 1987 the average production per well has decreased to 100 barrels/day. Oil production in the Cepu field during the Pertamina period again peaked in 1991-1992 [15].

The management of oil mines that are left entirely to mining companies sometimes only thinks about themselves how to make as much profit as possible without caring about the condition of the community around the mine as long as the work contract is in the hands of the company that has been appointed by the Cepu Block [16]. This also happens in many oil fields in Indonesia. If you want the management of the Oil Mine as a non-renewable resource such as the Cepu Block, it still prioritizes the preservation of natural resources and the welfare of the community, it depends on the concern for the approach and purpose of utilization used. 
The application of the wrong management system to the Cepu Block mining was the source of the conflict which culminated in riots or riots that forced mining companies to change the work contact system that had been signed by the appointed company. Cepu Block in mining management in the Cepu area, the results of oil management in Cepu are not divided equally but based on the number of wells managed and the number of group members. Oil is a nonrenewable resource, so the sustainability of livelihoods that depend on mining is very vulnerable, on the other hand, price control rests with Pertamina as the owner of the well [17]. In 1987 the Cepu Block oil mine was included in Pertamina's mining control, then on August 3, 1990, a Technical Assistance Contract (TAC) was signed between Pertamina and PT. Hummus Petra Gas (HPG) [18]. In 1999 ExxonMobil Corporation and Mobil Corporation merged to form ExxonMobil Corporation. Mobil Cepu Ltd a subsidiary of ExxonMobil obtains the remaining 50\% of HPG's contact interest and takes over the rights as the operator for TAC Cepu and gets approval from Pertamina and the Government of the Republic of Indonesia.

Based on this, ExxonMobil held a Head of Agreement (HOA) in June 2004. The government is responsible for the operation of the Cepu Block related to the national economic problems the government is facing. However, since the signing of the HOA in 2004, Pertamina's directors have not followed up the negotiations so that the management of the Cepu Block has become unclear, based on this condition the government through the Minister of State-Owned Enterprises has formed a team to negotiate the formation of problems between Pertamina and Exxon Mobil [19].

Since the plan, the operation of the Cepu Block oil mine has become a public concern that the Indonesian side still has to get approval from the Oil and Gas Management Agency (BP Migas). Under Oil and Gas Law No. 22/2001, BP Migas is an institution that has the authority to oversee the exploration and exploitation of upstream oil and gas activities. But in reality, the Cepu Block Management needs to carry out social and environmental responsibilities for the surrounding community. In 2002, the revenue of the Blora Regency government from mining products managed by Exxon Mobil amounted to Rp. 3.9 billion. This value is a regional participating interest (PI) which is relatively small and has not been able to improve the welfare of the community.

\subsection{Mining in Islamic perspective}

The basis of the country's economic development in the view of Islam must have a farreaching goal, namely increasing the welfare of the world and the hereafter. Therefore, development must refer to or be based on sharia provisions, both the word of God, the words of the Apostle, ijma, qiyas, as well as the ijtihad of the fiqh scholars. The word 'ulama' from the Arabic plural form of 'alim' is mentioned twice in the Qur'an: "Indeed, those who fear Allah among His servants are only scholars. Verily Allah is Mighty, Most Forgiving." The meaning of 'ulama' is generally defined as a useful teacher of knowledge, not only religious knowledge but also exemplary behavior [20].

Human development as a whole is the priority in Islamic economics. Not only building the people's economy but also building a mental attitude of robbaniyah (mental attitudes) by imitating the character of the ulama. Spiritual development automatically encourages independence, and everyone's awareness to build themselves, build the nation and mankind [21].

The concept of Islamic economic development reviews several elements of the concept according to some recent development literature, namely an increase in overall economic productivity and the average worker and also an increase in the ratio of income to the total 
population. This is a dynamic and structural process resulting in continuous, actual, and potential improvements to the economic outlook. Usually calculated in per capita terms spanning a certain period. Its substance lies in the ability of humans to control their economic environment as well as their quality of life [22].

Indonesia's economy is just impulsively by the provisions of sharia, in line with what was stated by the chairman of the DPP of the Indonesian Islamic Economist Association (IAEI), Agustianto. It was explained that the history of the Islamic economic movement in Indonesia has been going on since 1911, since the establishment of the Islamic Trade Union organization which was founded by businessmen and Muslim leaders at that time. The current development of the sharia economy can be said to be a reflection and longing of Indonesian Muslims to revive this spirit, in line with the teachings of the Prophet Muhammad and the Sunnah that are exemplified to his people.

Seeing the 1945 Constitution which explains that the natural wealth contained therein is controlled by the state and used for the greatest prosperity of the people. This is in line with the hadith of the Prophet which forbids monopolizing natural wealth, in a valid hadith through the sand of Ibn Umar Ra. (Narrated by Baihaqi), from the narration of Imam Ahmad it is said; "That I was fighting with the Apostle Sallalahu Alaihissalam, then I heard directly the Apostle Sallalahu Alaihissalam said, "Humans are united in three things in weeds, in matters of water and fire". Hadith narrated by Ahmad and Abu Dawud, takridj Imam Ibn Hajar al-Asqalani; The hadith is strong and reliable [23].

This is further clarified through the hadith narrated by Abu Hurairah which reads; "Three things should not be monopolized until it prohibits others from using them, namely water, weeds, and fire [24]. Apart from having the right to use it, there is also the right of others to use it. Meanwhile, the meaning of association here is to take collective benefit, allowing each other to enjoy and take advantage of it.

The beginning of this hadith implies the command for common ownership that no one can monopolize ownership, consequently freedom for every Muslim to use it. In these three affairs as joint property, there is no individual exclusive right to control it as a personal interest, so it is not permissible to prevent it if someone else needs it.

Regarding the economic development of Hamka Haq in his book Islam Rahmah for the Nation, it is said that to build an Islamic economy and theological technology several things must be considered, among them, firstly applying Islamic values, namely in accordance with Islamic law. Such as the termination of the practice of usury and ghoror, namely contracts or forms of cooperation agreements that are not clear. Second, the principle of halal ownership. Islam recognizes the existence of private and group property rights so that it is unlawful to control and trade other people's property or stolen goods and all kinds of goods obtained in vanity. Third, cooperation. As we know that Islamic economics departs from the belief that togetherness and partnership are the basic principles. No one can live and grow alone without other people, especially in the economic aspect. All buying and selling activities, debts, mortgages, grants, partnerships, land cultivation, trade, industry, and service businesses are the result of related cooperation. All of these parties must benefit each other in a fair and balanced manner. Fourth, fairness and transparency. Economic activities should bring benefits to all parties involved, without causing harm, and be explained by a clear and transparent mechanism. Armed with the principle of fairness and transparency, it is hoped that it will foster a healthy and conducive business climate, avoiding speculative elements and avoiding capitalistic power. Fifth, the public good. One of the main objectives of Sharia is to foster the general benefit after maximum justice and transparency are realized. This goal can only be achieved if aspects of life support each other and must not sacrifice other sectors let alone damage social life in general. 
A company can harm society and the environment. For example, exposure to toxic B3 waste, the impact of activities that cause disease, decreased quality of drinking water sources, contamination of food sources, and so on. If there is one or even all of these impacts, the activity that should be beneficial is something that is unjust and is strictly prohibited by sharia principles. Sixth, legality. Every business related to the interests of the people must be based on legal rules based on state law and sharia principles, especially economics. Efforts carried out illegally because they are not following the law and do not fulfill obligations to the State are clearly forbidden by religion. For example, illegal mining is based on the obligation to obey Allah and the Messenger of Allah, peace, and blessings of Allah be upon him. Seventh, growth (profit) and independence. By prioritizing prudence and the principle of no loss and no harm, this smallscale petroleum mining business needs to be appreciated. Each party involved should be free from coercion, away from tyrannical intentions, and open up job opportunities for the local people. By prioritizing prudence and the principle of no loss and no harm, this small-scale petroleum mining business needs to be appreciated. Each party involved should be free from coercion, away from tyrannical intentions, and open up job opportunities for the local people. By prioritizing prudence and the principle of no loss and no harm, this small-scale petroleum mining business needs to be appreciated. Each party involved should be free from coercion, away from tyrannical intentions, and open up job opportunities for the local people [25].

Looking at several explanations related to Islamic mining, the author argues that if someone wants to build a business that is taken from the wealth of the earth, one of which is oil or gas mining, the business actors should pay attention to the welfare of the surroundings, both the people and the surrounding environment. This is done to avoid an injustice that violates the principles of Islam.

\section{Conclusion}

This study resulted in the findings that, several Islamic principles must be considered by every business actor, be it mining business actors or others. Among the things that must be considered are, first, legal (not illegal) business ownership. both cooperation based on justice, especially in the distribution of results. Third, a business actor should be transparent to his employees, without any hidden personal interests for his welfare (capitalistic). Fourth, the public good. This is important for business people to pay attention to. Benefits must be numbered in building a business. If in the context of petroleum mining, the surrounding benefits must be considered, both the community and the environment so as not to be damaged due to the mining business activities carried out. If these principles are applied by business actors, including in petroleum mining, then this business activity will run well and correctly. Because if the business is not carried out properly and correctly, in this case, the Islamic principles as described, then the business actor will receive a bad impact from his business activities.

\section{References}

[1] Litbang EP Pertamina dan Fakultas Ekonomi Unpad, Studi Analisa Sumberdaya, Cadangan, dan Produksi Negara-negara OPEC \& Non OPEC. Bandung: Litbang EP Pertamina, 1988.

[2] Purnomo Yusgiantoro, Ekonomi Energi Teori dan praktik,. Jakarta: LP3ES, 2000.

[3] Agus Sofyandi Kahfi, “'Informasi Dalam Prespektif Islam,"” J. Terakreditasi Dirjen Dikti, no. 56, p. 323, 2005. 
[4] S. Risdiyanta, “Mengenal Kilang Pengolahan Minyak Bumi (Refinery) Di Indonesia,"” "Mengenal Kilang Pengolah. Miny. Bumi Di Indones., vol. 5, p. 4, 2012.

[5] Rahajeng Kusumo Hastuti, "Intip Progress Jambaran-Tiung Biru, Blok Gas Andalan di Jawa," 30 September, 2019. .

[6] Prahara Iqbal dan Undang Mardiana, "Evaluasi Cadangan Minyak Zona A dan B, Lapangan Ramses, Blok D Melalui Pemodelan Geologi Berdasarkan Data Petrofisika,” Teknol. Indones., vol. 32, no. 1, pp. 45-53, 2013.

[7] P. Pri, "Membandingkan kondisi lapangan dan perilaku sosial penambangn Wonocolo dan Ledok," 2018.

[8] Chaerudin dkk, Startegi Pencegahan dan Penegakan Hukum Tindak Pidana Korupsi. Bandung: P.T. REFIKA ADITAMA, 2008.

[9] Supraptono, "PPML Ledok," 2018.

[10] Barwis, John H., John G. McPherson, and Joseph RJ Studlick, Sandstone Petroleum Reservoirs. USA: Springer Science \& Business Media, 2012.

[11] Sugiharto, "Legalisasi Tambang Rakyat Lebih Menguntungkan," 2 februari, 2016. .

[12] Undang-Undang Republik Indonesia, Undang-Undang Republik Indonesia Nomor 8 Tahun 1971 Tentang Perusahaan Pertambangan Minyak Dan Gas Bumi Negara. indonesia, 1971.

[13] Direktorat Jenderal Minyak Dan Gas Bumi, “'Mewujudkan Ketahanan Energi,'” J. Migas, no. 2, p. 73, 2019.

[14] B. Yusran, Pengaruh Kegiatan Penambangan Tradisional Minyak Bumi Pada Sumur Tua Terhadap Kualitas Air Sungai (Studi Kasus Penambangan Tradisional Minyak Bumi Di Desa Wonocolo Kecamatan Kedewan Kabupaten Bojonegoro). semarang: Mrs Ekana Perpus Pasca, 2018.

[15] P. E. Cepu, “Annual Report Pertamina EP Cepu,” Cepu, 2017.

[16] Fahmi Rochmaningrum, “Perkembangan Tambang Minyak Blok Cepu Dan Pengaruhnya Terhadap Sosial Ekonomi Masyarakat Desa Ledok Tahun 1960-2004,'” J. Indones. Hist., vol. 1, no. 2, p. 122, 2012.

[17] Anwar Sanusi, Metode Penelitian Bisnis. Jakarta: Salemba Empat, 2011.

[18] Ida Ayu Sabrina Putri, Tinjauan Yuridis Proses Peralihan Technica Assistance Contract (TAC) menjadi Produsen Sharing Contract (PCS) Studi Kasus Blok Cepu. Jakarta: : FH UI, 2015.

[19] Marwan Batubara, Tragedi dan Ironi Blok Cepu Nasionalisme yang Tergadai,. Jakarta: Indonesian Resourcess Studies, 2011.

[20] Al-Qur'an Surat Fathir, ayat: 28. .

[21] Agung Eko Purwana, "Pembangunan Dalam Perspektif Ekonomi Islam," Justitia Islam., vol. 10, no. 1, p. $17,2013$.

[22] Tira Nur Fitria, “"Kontribusi Ekonomi Dalam Pembangunan Nasional,"," J. Ilm. Ekon. Islam, vol. 2, no. 3, p. 37, 2016.

[23] ibnu Hajar Al-Asqalani, bulughul marram. Jakarta: Mizan, 2010.

[24] ibnu majah abu abdillah muhammad, sunan ibnu majah. Beirut: Dar al-Fikr.

[25] Hamka Haq, Islam : rahmah untuk bangsa,. Jakarta: RMBooks, 2009. 